\title{
Relation of prevalence of physical activity with psychological variables and factors of metabolic syndrome in prison agents in Belo Horizonte, MG, Brazil
}

\author{
Relação da prevalência de atividade física com variáveis psicológicas e componentes \\ da síndrome metabólica em agentes penitenciários de Belo Horizonte-MG
}

\section{Ramon Emmanuel Braz Ferreira' Lígia Carlos Menezes' João Carlos Dias'}

1. Centro Universitário de Belo Horizonte - UNI-BH, Departamento de Ciências Biológicas, Ambientais e da Saúde

\begin{abstract}
The prison population in Brazil has been growing. The prison agent (PA) is the professional who works in the security sector, having the tasks of conducting prisoners and vigilance inside the facilities, and escorting the prisoners to outside, as well. The agents have a busy and stressing life and they do not have time and facilities to physical exercise practice. Therefore, the objective was to relate the prevalence of physical exercise with metabolic syndrome, with trace and state anxiety, and with minor psychological disturbs in agents in Belo Horizonte, MG, Brazil. Also habits of life, physical exercise and clinical parameters were characterized. One hundred and one agents took part in this study, as volunteers, from 3 different prison units. The male average $(n=76)$ age and standard deviation of the sample was $33.1 \pm 5.7$ years old and $4.8 \pm 3.4$ years working as PA. It was evident that the majority uses alcoholic beverages (63\%) and $97.3 \%$ classified their job as very dangerous. Considering males, where the greater alterations in MS factors were found, smokers represented $26.3 \%$ and altered glucose concentration was present in $27.6 \%$ of the sample. Smaller values were found $(p<0.05)$ for: glucose in agents who practice $\left(101.0 \pm 14.9 \mathrm{mg}^{\left.-\mathrm{dl}^{-1}\right)}\right.$ compared with non practitioners $(111.9 \pm 21.5$ $\left.\mathrm{mg} \cdot \mathrm{dl}^{-1}\right)$ and arterial pressure (122.3 \pm 8.0 and $131.3 \pm 11,5 \mathrm{mmHg}$, respectively). Body mass index (BMI) in practitioners and non practitioners were $26.4 \pm 3.8$ and $29.6 \pm 6.1 \mathrm{~kg} \cdot \mathrm{m}^{-2}$, and waist circumference $91.6 \pm 9.7$ and $99.7 \pm 16.7 \mathrm{~cm}$, respectively, were also smaller $(p<0,05)$. It was concluded that there were greater alterations in the metabolic profile in males non practitioners of physical exercise in the three prisons institutions studied, because it was found systolic arterial pressure, BMI, waist circumference and blood glucose with statistically significant different values $(p<0.05)$ compared with practitioners of physical activity.

Keywords: Prison agent; Physical exercise; Metabolic syndrome; Minor psychological disturbs; Health.
\end{abstract}

\section{Resumo}

É crescente a população carcerária no país. O agente penitenciário (ASP) é o profissional que presta serviço junto ao setor de segurança, tendo como funções o acompanhamento e vigilância dos presos nas dependências das unidades prisionais e realizando também escolta de presos. Os ASP têm uma vida atribulada e estressante e não possuem tempo e nem instalações para a prática de exercícios físicos. Assim o objetivo do estudo foi relacionar a prevalência da prática regular de exercícios físicos com a síndrome metabólica, com a ansiedade de traço e de estado, e com distúrbios psíquicos menores em ASP de Belo Horizonte, MG. Também foram caracterizados os hábitos de vida, frequência de exercício físico e parâmetros clínicos dos ASP. Participaram do estudo 101 ASP de três unidades Prisionais de Belo Horizonte. A média e desvio-padrão de idade da amostra masculina $(n=76)$ foi de $33,1 \pm 5,7$ anos e com $4,8 \pm 3,4$ anos de trabalho. Verificou-se que a maioria da amostra faz o uso de bebidas alcoólicas (63\%) e que $97,3 \%$ consideram seu trabalho muito perigoso. Ainda com relação ao sexo masculino, onde ocorreram as maiores alterações de componentes da SM, os agentes fumantes representam $26,3 \%$. Foram encontrados valores menores $(p<0,05)$ : na glicemia de jejum de praticantes $\left(101,0 \pm 14,9 \mathrm{mg} \cdot \mathrm{dl}^{-1}\right)$, comparados com não praticantes $\left(111,9 \pm 21,5 \mathrm{mg} \cdot \mathrm{dl}^{-1}\right)$ e de pressão

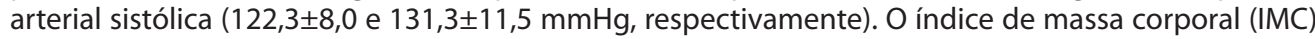
de praticantes e não praticantes foi $26,4 \pm 3,8$ e $29,6 \pm 6,1 \mathrm{~kg} \cdot \mathrm{m}^{-2}$ e a circunferência da cintura $91,2 \pm 8,7$ e $100,1 \pm 13,9 \mathrm{~cm}$, respectivamente, também foram menores $(p<0,05)$. Conclui-se que houve maiores alterações no perfil metabólico dos agentes penitenciários do sexo masculino que não praticaram exercício físico nas três unidades prisionais estudadas, pois, encontrou-se pressão arterial sistólica, índice de massa corporal, circunferência da cintura e glicemia em jejum com valores significativamente diferentes (para $\mathrm{p}<0,05$ ) comparados com não praticantes de atividade física.

Palavras-chave: Agente penitenciário; Exercício físico; Síndrome metabólica; Distúrbios psíquicos menores; Saúde. 


\section{INTRODUCTION}

The prison population has been growing in Brazil. The institutions for prisoners are becoming more and more overcrowded and handling the prisoner has grown increasingly difficult. The correctional officer is the professional who provides services in the security sector, whose tasks are the supervision and surveillance of prisoners on the premises of the prison unit. This professional's activity is developed without the use of firearms inside the units (galleries), and only truncheons, the tonfa and handcuffs are employed for defense and prisoner immobilization. Whenever necessary, in the walls, entrance gates, watchtowers, around the security area of the Prison Units and while escorting prisoners, the correctional officer has the prerogative of using firearms.

In view of these functions, it can be stated that the correctional officer has a busy and distressing life. As the correctional officer is in direct contact with the prisoners, and is seen by them as one of the people who are responsible for the maintenance of their confinement, this professional is frequently exposed to diverse situations that generate psychological manifestations, such as intimidations, aggressions, threats, and the possibility of rebellions, in which, among others, he/she runs the risk of being killed or becoming hostage (1). Furthermore, there is the possibility of escapes, fights among inmates and between factions. Therefore, this professional needs better technical preparation which includes physical conditioning, so that they can better develop their functions in the Prison System.

Correctional officers have neither time nor facilities for exercise practice, unlike other corporations like the Armed Forces and the Military Police, which have a number of hours allocated to physical exercise. Physical activity produces many benefits, as established in the guidelines issued by the American College of Sports Medicine (2). Benefits of regular physical activity or physical exercise include: a) increase in the feeling of wellness; b) increase in work performance; c) decrease in anxiety and depression.

Physical inactivity, in turn, brings many problems, like obesity, for example. Excessive fat, mainly visceral fat, has been resulting in a large number of deaths. Obesity causes countless complications, such as glucose intolerance and lipid profile disorders, known as metabolic syndrome $(3,4)$.

The term metabolic syndrome (MS) has been suggested by the World Health Organization, according to Souza et al. (5). This syndrome was described for the first time by Reaven in 1988 (6), but it was observed in the 1980s, when it was verified that dyslipidemia, arterial hypertension and hyperglycemia were associated conditions and resulted in higher cardiovascular risk, being called X Syndrome (7). Thus, MS was identified as a grouping of cardiovascular risk factors, such as arterial hypertension, poor glycemic control, abdominal obesity and dyslipidemia (8). This syndrome plays a relevant role in the genesis of cardiovascular disease in obese individuals. The common aspect of the syndrome is insulin resistance and it is likely that all the other alterations, such as glycemia, obesity and high blood pressure are secondary to this basic anomaly, which has been shown to increase the risk of coronary artery disease (9). One of the aspects related to risk of metabolic syndrome is the person's lifestyle concerning psychological disorders $(10,11)$.

Anxiety symptoms are extremely frequent in clinical practice and usually present themselves as a mixture of somatic manifestations (like tachycardia, tremors, sudoresis, dry mouth, hyperventilation, among others), behavior manifesta- tions (agitation, insomnia and fears, for example), and cognitive manifestations (apprehension, nervousness, preoccupation, irritability and lack of attention) (12).

Some authors distinguish between state anxiety and trait anxiety $(13,14)$. State anxiety is a transitory emotional state, a condition of the organism that is characterized by feelings of tension and apprehension that are consciously perceived and which vary in intensity over time. Trait anxiety refers to stable individual differences in propensity to anxiety; it is the way in which the person tends to react in situations perceived as threatening. People with high levels of trait anxiety tend to present also high levels of state anxiety, as they react more frequently to situations as if they were threatening or dangerous $(13,14)$. According to Rumin (15), correctional officers are exposed to anxiogenic situations, like the imminent risk of violence in the daily working routine, and this violence may extend and affect their relatives - the worker and his/her relatives may be recognized by the inmates' relational network in the social spaces.

When the manifestations of anxiety are very intense, they may lead to the state of stress, which is the consequence of internal and external conditions and their proportions. In 2008, Lipp (16) presents the three-stage model of stress evolution proposed by Selye in 1956. The model, called "general adaptation syndrome", comprehends three stages: alarm reaction, resistance and exhaustion. The stage of alarm reaction occurs when the person faces the aggressor and has physiological responses to fight and flight. The problem is when physiological promptness is not necessary or is excessive. The resistance stage occurs with a stressor of long duration or intensity and the organism uses reserves of adaptive energy to rebalance itself. The problem is when the stressor requires more adaptation effort than is possible to that individual - the organism weakens and if the person's resistance is not enough or other stressors occur, the stage of exhaustion emerges. In the exhaustion phase, there will be an increase in the lymphatic structures, leading to psychological exhaustion, depression and, consequently, to the development of diseases. Thus, teachers, nurses, social workers and police officers, any person who faces persistent problems at work may become worn-out by the unceasing stress of his/her functions. The result may be a sharp decrease in performance caused by physical exhaustion, depression caused by emotional exhaustion and skepticism caused by mental exhaustion (17).

In view of the correctional officers' situation, and in light of their daily routine, studies have been developed in other Brazilian states. Studies carried out in the city of Londrina (Southern Brazil) have investigated correctional officers' psychological aspects (18). Other studies have shown an association among absence of sports practice, psychologically inadequate work environment and minor psychological disorders (1). Among the study's findings, 31\% of the officers presented minor psychological disorders and $22 \%$ had stress (1).

Police and correctional officers have been referred by Tartaglini and Safran (19) as professionals submitted to high risk of stressful and debilitating diseases. These authors have found higher prevalence of anxiety, behavior disorder and alcohol abuse among correctional officers when compared to the general population. They reported an $18.6 \%$ prevalence of emotional disorders, $4.5 \%$ of alcohol abuse and $7.9 \%$ of anxiety disorders. In another study carried out in France with all the categories of prison workers, Goldberg et al. (20) observed prevalences of $24 \%$ of depressive symptoms, $24.6 \%$ of anxiety disorder and $41.8 \%$ of sleep disorder. The largest part of the 
reviewed studies has investigated the prisoners' health status. Few studies have focused on the correctional officers' health in the state of Minas Gerais, and no Brazilian study has related the correctional officers' physical activity or physical exercise to stress, anxiety and metabolic syndrome.

Based on the information above, the present study aimed to relate prevalence of physical activity to components of the metabolic syndrome, to trait and state anxiety, and to minor psychological disorders in correctional officers in the city of Belo Horizonte, state of Minas Gerais (Southeastern Brazil). Another aim was to characterize life habits, frequency of physical exercise and clinical parameters of the sample.

\section{METHODS}

The study was classified as descriptive, as it reports on the phenomenon without manipulating the variables. The study's design established 2 groups, physical activity practitioners and non-practitioners, to identify differences between groups in relation to variables connected with the metabolic syndrome, coronary artery disease risk, anxiety and psychological disorders. The aim was to study the relationship between physical exercise and these variables (21).

A random sample was selected, stratified by the correctional officers' work shift. Thus, daytime and nighttime workers are represented in the sample. This study was approved by the Research Ethics Committee of Centro Universitário de Belo Horizonte (UNIBH). After the research's objectives were explained and anonymity was guaranteed, the participants signed an informed consent form.

The study assessed 101 volunteers (75 men and 25 women), both in the daytime and nighttime periods, without skin color distinction, from three prison units of Belo Horizonte: Centro de Remanejamento do Sistema Prisional- CERESP/BH, Complexo Penitenciário Feminino Estevão Pinto, and CERESP São Cristovão. The correctional officers who were not fit for professional exercise and those who performed administrative activities were excluded from the study. In this study, the following questionnaires were administered: life habits (18), trait and state anxiety (22), minor psychological disorders (1), and coronary artery disease risk (2). Among the questions, the correctional officers were asked whether they practiced physical exercises for at least 20 minutes, three times a week, which classified them as practitioners or non-practitioners of physical exercise. Aspects related to obesity and metabolic syndrome $(9,12)$ were studied, and data like type of service, time in the profession and number of working hours were collected. A meeting was held with the directors and volunteers of the prison units in order to explain the study's objectives. After authorization was granted, all the volunteers answered the questionnaires together in a room, in the presence of the researcher, and afterwards they were individually taken to the nursing ward for the collection of anthropometric data and blood glucose.

The questionnaires that were used are validated and have been employed in other studies, but some were modified so as to adapt them to Minas Gerais' prison system, or to exclude questions that appeared in another questionnaire, in order to avoid redundancies. The questionnaire about life habits (18) aims to survey data concerning daily life at the workplace (work shift, job, addictions like smoking and alcohol consumption, and the regular practice of physical activity). This questionnaire contains questions like: do you smoke or have you ever smoked? How do you rate your health? Do you practice physical activity regularly? How often do you drink? (18).
The questionnaire about trait and state anxiety (22) measures trait anxiety, which is characteristic of the person, and state anxiety, which is influenced by the situation and by the environment. In this questionnaire, 20 questions refer to trait anxiety and 20 to state anxiety, and it contains statements like: I feel good (trait), I feel calm (state). Based on these statements, the person must mark the number ( 1 to 4 ) that best indicates how he/she generally feels (22). The Self-Reported Questionaire (SRQ-20) assesses the existence of minor psychological disorders. This instrument contains 20 questions with dichotomous options of answers (yes/no). Some of the questions are: Do you have frequent headaches? Do you have lack of appetite? (23) The questionnaire about risk of coronary artery disease that was used was the one established by the Guidelines of the American College (2), and contains positive and negative risk factors. The person answers it with the aid of the researcher and attributes an answer (yes/no/does not know) to factors like hypercholesterolemia, altered fasting glucose, triglycerides, family history of heart diseases, etc.

After answering the questionnaires, the subjects went to the nursing ward and their body mass was measured by a 100g graduated Welmy ${ }^{\circledR}$ scale. Subjects were barefoot, wearing only their uniforms, standing with their back to the machine's scale in anatomical position, with their body mass equally distributed. The Body Mass Index (BMI) was calculated by dividing the body mass in $\mathrm{kg}$ by the square of the height in meters. Body mass and height were measured twice, and the mean of the two measures was used to calculate the BMI. To determine the individuals' total height, a stadiometer fastened to the Welmy ${ }^{\circledR}$ scale was used. The person was measured barefoot, standing in anatomical position on the basis of the stadiometer, with his/her back part of the body touching the stadiometer and the head positioned in the Frankfurt plane, in inspiratory apnea at the moment of the measure (24). Waist circumference (WC) was measured at a level midway between the lowest rib and the iliac crest, with an anthropometric tape of the brand Cescorf ${ }^{\circledast}$, with a $0.1-\mathrm{cm}$ scale. WC was measured twice and a third measure was performed when there were differences above $0.1 \mathrm{~cm}$ between the measures. The mean of the two measures was used in the analyses.

Blood pressure was measured through the auscultatory method. Systolic blood pressure and diastolic blood pressure were measured in the person's right arm by means of a mercury column sphygmomanometer (brand: Unilec), positioned at the heart's level, and by a stethoscope of the brand Premium. Measurement was performed after the individual had remained sitting at rest for a period of 10 minutes. Two consecutive readings were made with an interval of 10 minutes between the measurements, and the mean value was considered. Fasting blood glucose was measured with a glucometer of the brand Accu-Chek Active (Roche), by means of the collection of a drop of blood of each individual for glycemia analysis, with a small hole made by a disposable needle in the index finger of the researched subjects. The nursing assistants of the prison units were present and aided the researcher.

Regarding cutoff points, situations and values were defined as follows: Correctional officers who performed at least 20 minutes of physical exercise at least three days a week were categorized as practitioners. Cutoff points for MS diagnosis were the ones adopted by the National Cholesterol Education Program (NCEP), which in 2001 established five parameters for adults: abdominal circumference $(>102 \mathrm{~cm}$ in men and $>88 \mathrm{~cm}$ in women), fasting trygliceridemia $>130 \mathrm{mg} / \mathrm{dL}$ serum levels of the high density fraction of cholesterol (HDL) 
$<40 \mathrm{mg} / \mathrm{dL}$; blood pressure above percentile $90(130 \mathrm{mmHg})$ and fasting glucose $\geq 110 \mathrm{mg} / \mathrm{dL}$. Alterations in at least three of these parameters confirm the MS diagnosis, as cited by Souza et al. (23). Alcohol abuse was defined by the authors as subjects drinking alcohol more than 4 times per week and amounts of drinking reported by the correctional officers as "much" or "excessive". This definition was adopted in view of the fact that the questionnaire differs from the main sources on the matter $(25,26)$. For the SRQ20 test, the cutoff point was defined as score 7 (27). For state and trait anxiety, mild anxiety was considered as score below 33, moderate from 33 to 49 and high, above 49 (22).

The questionnaires were numbered and there is only one list with subject's name and number. Only one researcher handled the list that contains the name to guarantee the secrecy of individual data. The results were tabled in the statistical program SPSS version 15 and treated in a qualitative way, with the use of simple statistical tools like count, percentage, mean, and standard-deviation. They were presented in tables or graphs. Student's t-test for independent samples was used to verify the existence of significant differences in the comparison of subjects who practiced physical exercise with those who did not. $P$ value was previously established as $\mathrm{p}<0.05$. The chi-square test was also used to verify if there is a different relationship between health and security indicators and practice of physical activity in men and women.

\section{RESULTS}

The study had the participation of 101 correctional officers from three prison units of Belo Horizonte. Table 1 presents data of the whole sample and of men and women separately.

Variables that indicate health and security were studied in men and women. The percentages were calculated and are presented on Table 2, which includes the significance of the analysis between men and women when the chi-square test is applied.

Table 3 presents results related to risk factors, state anxiety, trait anxiety and SRQ in the sample of male non-practitioners and practitioners of physical exercise.

\section{DISCUSSION}

The main objective of the present investigation was to study the relation of the prevalence of practice of physical exercise to psychological and physiological variables and also with factors of the metabolic syndrome. An important variable on Table 2 is the prevalence of physical exercise, which is an object of this study. The professionals answered whether they practiced physical exercise in their spare time at least three times a week. Of a total of 25 women, only 3 stated they practiced physical exercise, which invalidated the comparison between female practitioners and non-practitioners. Thus, only the men were divided into practitioners and non-practitioners, as presented on Table 3.

Table 3 shows results that demonstrate the importance of physical activity, even when practiced due to the correctional officers' interest in their spare time. Blood pressure, BMI, abdominal perimeter and glycemia were significantly different when practitioners and non-practitioners were compared. In addition, it can be observed that practitioners and non-practitioners have similar height, but different body mass, which suggests that the non-practitioners of physical exercise have higher body weight as regards adipose tissue.

In the operating sector there are more men than women among the correctional officers in the entire national territory, due to the fact that there are more male than female prisoners. In the case of Belo Horizonte, in the three prison units that were studied, there are, overall, 628 correctional officers (433 men and 195 women) to attend to a prison population

\begin{tabular}{|c|c|c|c|c|c|c|c|c|c|}
\hline & $\begin{array}{c}\text { Age } \\
\text { (years) }\end{array}$ & $\begin{array}{c}\text { Body mass } \\
\text { (kg) }\end{array}$ & $\begin{array}{c}\text { Height } \\
\text { (meters) }\end{array}$ & BMI & $\begin{array}{l}\text { WC } \\
(\mathrm{cm})\end{array}$ & $\begin{array}{l}\text { Systolic } \\
\text { pressure } \\
(\mathrm{mmHg})\end{array}$ & $\begin{array}{l}\text { Diastolic } \\
\text { pressure } \\
(\mathrm{mmHg})\end{array}$ & $\begin{array}{c}\text { Fasting } \\
\text { glycemia } \\
(\mathrm{mg} / \mathrm{dl})\end{array}$ & $\begin{array}{c}\text { Years of } \\
\text { service }\end{array}$ \\
\hline $\begin{array}{c}\text { Total mean } \\
\text { SD }\end{array}$ & $33.5 \pm 5.9$ & $80.6 \pm 17.6$ & $1.72 \pm 0.09$ & $26.9 \pm 4.9$ & $91.6 \pm 12.9$ & $125.1 \pm 11.0$ & $83.2 \pm 9.8$ & $105.7 \pm 18.2$ & $4.8 \pm 3.8$ \\
\hline $\begin{array}{c}\text { Mean } \\
\text { Women SD }\end{array}$ & $34.8 \pm 6.5$ & $67.0 \pm 10.7$ & $1.64 \pm 0.08$ & $24.6 \pm 3.3$ & $81.9 \pm 10.6$ & $122.3 \pm 12.1$ & $80.4 \pm 10.0$ & $106.5 \pm 15.9$ & $4.7 \pm 4.7$ \\
\hline $\begin{array}{c}\text { Mean } \\
\text { Men SD }\end{array}$ & $33.1 \pm 5.7$ & $85.4 \pm 17.1$ & $1.75 \pm 0.07$ & $27.8 \pm 5.1$ & $94.9 \pm 11.9$ & $126.0 \pm 10.5$ & $84.1 \pm 9.6$ & $105.5 \pm 18.6$ & $4.8 \pm 3.4$ \\
\hline
\end{tabular}

$\mathrm{SD}=$ standard-deviation; $\mathrm{n}$ women=25, $\mathrm{n}$ men=76. $\mathrm{BMI}=$ Body Mass Index. $\mathrm{WC}=$ Waist Circumference. estatística qui-quadrado (p)

\begin{tabular}{lccc}
\hline \multicolumn{1}{c}{ Variable } & \multicolumn{2}{c}{ Percentage } & \multirow{2}{*}{ Chi-square } \\
\hline Use of alcoholic beverages & 63.1 & 60.0 & 0.81 \\
Perception of insecurity at the workplace & 97.3 & 64.0 & $0.001^{*}$ \\
Smokers & 26.3 & 13.0 & 0.19 \\
Prevalence of physical exercise & 59.2 & 13.0 & $0.001^{*}$ \\
Fasting glucose above 110 $\mathbf{m g} / \mathbf{d l}$ & 35.5 & 36.0 & 0.77 \\
Blood pressure above 130-85 $\mathbf{~ m m H g}$ & 27.6 & 24.0 & 0.72 \\
Perception of health status & 50.0 & 65.2 & 0.24 \\
\hline
\end{tabular}

* Significant difference $(\mathrm{p}<0.05)$ 


\begin{tabular}{lccc}
\hline \multicolumn{1}{c}{ Variables } & $\begin{array}{c}\text { Practitioners means } \\
\text { and standard- } \\
\text { deviation } \mathbf{n = 4 4}\end{array}$ & $\begin{array}{c}\text { Non- } \\
\text { practitioners } \\
\mathbf{n = 3 1}\end{array}$ & $\begin{array}{c}\text { t-test } \\
\mathbf{p}\end{array}$ \\
\hline Systolic pressure (mmHg) & $122.3 \pm 8.0$ & $131.3 \pm 11.5$ & $0.000^{*}$ \\
Diastolic pressure (mmHg) & $80.9 \pm 5.2$ & $88.7 \pm 12.3$ & $0.000^{*}$ \\
Body mass (kg) & $80.4 \pm 13.6$ & $91.8 \pm 19.6$ & $0.005^{*}$ \\
Body mass index & $26.4 \pm 3.8$ & $29.6 \pm 6.1$ & $0.006^{*}$ \\
Waist circumference (cm) & $91.2 \pm 8.7$ & $100.1 \pm 13.9$ & $0.001^{*}$ \\
Glycemia (mg/dL) & $101.0 \pm 14.9$ & $111.9 \pm 21.5$ & $0.011^{*}$ \\
State anxiety & $41.1 \pm 6.3$ & $41.7 \pm 6.1$ & 0.664 \\
Trait anxiety & $38.7 \pm 7.2$ & $42.9 \pm 6.6$ & $0.011^{*}$ \\
SRQ 20 & $2.4 \pm 2.7$ & $5.1 \pm 4.9$ & $0.003^{*}$ \\
\hline
\end{tabular}

* Significant difference $(\mathrm{p}<0.05)$.

composed of 1,612 men and 374 women.

The correctional officers of Belo Horizonte are young when compared to other studies. The mean age found in the general sample is $33.5 \pm 5.9$ years, with no difference between men and women. This is below the age risk for the age factor indicated by the American College of Sports Medicine (ACSM) in 2006 (2) (men older than 45 years and women older than 55 years are classified in a category of higher risk of coronary artery disease). The mean age of the study conducted by Fernandes et. al (1) was $40.2 \pm 7.7$ years, and the mean time subjects had been working as correctional officers was 10.3 \pm 5.8 years, well above the mean time of service in the prison units of Belo Horizonte ( $4.8 \pm 3.8$ years). These results of Belo Horizonte (younger officers with less time of service) suggest that the officers may be in more unfavorable conditions concerning MS factors in 7 years' time, when their age and time of service become similar to those of the study carried out by Fernandes et al. (1).

One of the problems that has been reported as being prevalent in tasks that are conducted in psychological stress environments is alcohol addiction. In the present study, the prevalence of alcohol use among correctional officers was verified. Table 2 shows that the major part of the sample uses alcoholic beverages $(63.1 \%$ for the men and $60 \%$ for the women). These results corroborate the study conducted by Fernandes et. al (1) with 311 interviewed officers, in which 68.5\% stated that they currently drank and only $14.8 \%$ reported that they had never consumed alcoholic beverages. Only $9 \%$ reported drinking 4 or more days a week and much or in excess, which was considered alcohol abuse by the authors. The work carried out by Costa et al. (28), which evaluated a sample of 264 military police officers concerning the consumption of alcoholic beverages, found only $35.6 \%$. Alcoholism has been considered an important stress indicator (30).

As regards the perception of security at work, the major part of the sample, both men and women, considered their job very dangerous. The men's results (97\%) corroborate the findings of Reichertet et al. (18), in which $90 \%$ of the correctional officers considered their work very dangerous. The lower percentage among women (64\%) may be due to the fact that they do not work in posts that are considered more dangerous, like entrance gates, GITAF (Grupo de Intervenção Tática Feminina - female tactic intervention group) and in the escort of inmates - only a small percentage of the studied women performed such services. In the study conducted by Souza et al. (5) with civil police officers, again the men, more than the women, perceive that there are risks in their current activity and that their families are also at risk. Studies have related lack of security to increase in psychological disorders like anxiety $(10,11)$.

The male officers who smoke represent $26.3 \%$, while $13 \%$ of the sample are female smokers. Concerning the amount of cigarettes, the smokers' mean was $20.2 \pm 13.7$ per day. In the study conducted by Portela and Filho (31), the findings were similar. Seventy-five percent of the police officers answered they do not smoke, $10 \%$ answered they smoke up to ten cigarettes per day, $10 \%$ from ten to twenty cigarettes and $5 \%$ from twenty to thirty cigarettes per day. These findings are worrisome, as the percentage of smokers is above the Brazilian average (17\%). Studies indicate that, compared to non-smokers, men and women who smoke approximately 20 cigarettes per day have, respectively, 3 to 6 times higher odds of suffering a myocardial infarction (32).

As for the prevalence of physical exercise in the correctional officers' spare time, $59.2 \%$ of the men and $13.0 \%$ of the women said they practice it. These data do not coincide with the study carried out by Fernandes et al. (2), in which the majority of individuals was classified in the preparation stage (do not practice physical activity regularly, but intend to start in the next 30 days). The high prevalence of active individuals in this study deserves to be questioned. The young sample or the location of the prison institutions in places that are distant from the city center may be the answer. Many correctional officers live close to the workplace and do not double work shifts, as in the study by Fernandes.

The frequencies of altered fasting glucose that were found are in accordance with other studies. In the study carried out by Silva (20) with 484 male police officers aged between 30 and 59 years, altered glucose values were found: between 100 and $125 \mathrm{mg} / \mathrm{dl}$ was prevalent in $28.7 \%$, between 126 and $199 \mathrm{mg} / \mathrm{dl}$ in $5.5 \%$ and above $200 \mathrm{mg} / \mathrm{dl}$ in $1.3 \%$ of the analyzed sample. Brazil presents high prevalence of high glucose levels (7.6\%), similar to that of more developed countries (33). When the mean values of fasting glucose are compared, the correctional officers who practiced physical exercises obtained lower means than the non-practitioners. Scientific evidence indicates that there are lower insulin levels, higher sensibility to insulin and greater protection against decline in glucose tolerance with aging in athletes, when compared to sedentary subjects (34). Moreover, the practice of physical ac- 
tivities is a factor of protection of glucose alteration in view of the fact that glucose enters the muscular cell independently of the action of insulin, reducing the serum concentration of glucose and the peripheral insulin resistance (34). The officers who do not practice physical exercises, even though they are younger and have been working as correctional officers for less time when compared to those in the study conducted by Silva (20), have already presented higher glucose values.

The prevalence of blood pressure above $130-85 \mathrm{mmHg}$ was high (27.6\%) compared to the results presented by Calamita et al. (35), who evaluated the prevalence of systolic blood pressure (Systemic Arterial Hypertension - SAH) in 900 police officers, and observed only $5.3 \%$ of hypertensive police officers in the sample. Taking the age group into account, in the group of police officers younger than 35 years, the authors found $\mathrm{SAH}$ in $3 \%$ of the officers, while in those aged 35 years or older, the prevalence of SAH was $6.8 \%$.

In the present study, good health status perception was found in both genders. The majority $(65.2 \%)$ of the women and $50 \%$ of the men rated their health as very good or good, which is similar to a study on the health perception of military police officers, in which Ferreira et al. (23) reported that the majority (68\%) perceive their general health status as positive (very good or good).

In the comparison of blood pressure means (Table 3), there was a significant difference between practitioners and non-practitioners of physical activities. This shows that the blood pressure of the practitioners is classified as normal, while that of the non-practitioners is borderline, that is, close to the hypertension values. Although the non-practitioners present a mean BMI that is higher than that of the practitioners, both presented values above normality, with classification for overweight. The diagnosis of overweight has also been found by Donadussi et al. (36), who, in their study of anthropometric indicators and obesity in 183 military police officers, found that the mean of $63.9 \%$ of the sample was above $26.6 \mathrm{~kg} / \mathrm{m}^{2}$.

Like the BMI, waist circumference also presented higher mean values in the non-practitioners compared to the practitioners. The literature has extensively shown the association between these clinical parameters, being able to identify individuals with overweight and other cardiovascular risk factors (37). Some authors argue that an important determinant to the development of MS in adult life is fast weight gain. Accumulation of adipose tissue, mainly in the abdominal region, is fundamental to trigger the MS (38).

In the present study, at least three parameters with alterations in the MS components were found, which suggests that the individuals of this sample who do not practice physical exercises have higher cardiovascular risk (5) despite their young age ( $33.5 \pm 5.9$ years) and although they have been in the profession for a few years ( $4.8 \pm 3.8$ years).

Regarding the data of the SRQ-20 stress tests, mean values of $2.4 \pm 2.7$ were found for practitioners and $5.1 \pm 4.9$ for non-practitioners of physical exercises (Table 3 ), which shows that the sedentary individuals had higher stress levels than the practitioners $(p<0.05)$. The results of the present study do not corroborate the study carried out by Souza et al. (5), in which, of the 2,746 civil police officers, men and women, who were studied, $20.2 \%$ presented psychological suffering based on the SRQ-20, that is, were above value 7, which may indicate presence of minor psychological disorders. Concerning the test of trait and state anxiety (Table 3), a higher mean was found among non-practitioners ( $42.9 \pm 6.6$ in trait anxiety and $41.7 \pm 6.1$ in state anxiety) compared to the practitioners, who obtained the mean of $41.1 \pm 6.3$ in trait anxiety and $38.7 \pm 7.2$ in state anxiety. This difference was significant to trait anxiety, but not to state anxiety, which suggests that in a larger sample, the differences would be significant.

Thus, this study presented a limitation in relation to the number of participant correctional officers. The female sample, even though representative, should have been larger because only a small number of women who practiced physical activities was found. The fact that this group was composed of only 3 women prevented the drawing of comparisons.

The study showed that individuals who do not practice physical exercises have a worse metabolic profile referring to glycemia alterations, waist circumference, BMI and blood pressure when compared to those who practice physical exercises. This result may indicate that correctional officers need to practice physical activities for MS prevention, and also for health promotion.

A recommendation for future research would be to conduct an experimental study based on this descriptive study in order to investigate the evolution of the psychological and physiological variables of the sedentary officers who started to practice physical exercises.

It is concluded that the correctional officers who do not practice physical activities from the three prison units that were studied present worse metabolic profile and, therefore, higher cardiovascular risk when compared to the practitioners. As for the psychological factors, the sedentary officers had a higher mean in the SRQ-20 when compared to the practitioners, and also in trait anxiety, but the differences were not significant for state anxiety, which suggests that a larger sample would be necessary. However, the whole sample presented a moderate level of psychological stress and anxiety, generally speaking, compared to other professions.

\section{Acknowledgements}

We would like to thank all the volunteers who contributed to the conduction of this study. The professionals who work at the Brazilian prisons experience great insecurity due to the overcrowding conditions, deficient facilities and lack of recognition from the society.

\section{REFERENCES}

1. Fernandes RCP, Neto AMS, SENA GM et al. Work in the prison system: a study of correctional officers in Greater Metropolitan Salvador, Brazil. Cad Saude Publica. 2002;18:807-816.

2. American College of Sports Medicine (ACSM) ACSM's Guidelines for exercise testing and prescription. 7aEd. New York: Lippincott Williams \& Wilkins, 2006.

3. Alberti KG, Zimmet P, Shaw J. Metabolic syndrome--a new world-wide definition. A Consensus Statement from the International Diabetes Federation. Diabet Med 2006; 23(5):469-80.

4. Seo JM, Park TH, Lee DY et al. Subclinical Myocardial Dysfunction in Metabolic Syndrome Patients without Hypertension. J Cardiovasc Ultrasound. 2011;19:(3)134-139.

5. Souza ER, Franco LG, Meireles CC, et al. Sofrimento psíquico entre policiais civis: uma análise sobre a ótica do gênero. Cad. Saúde Pública, Rio de Janeiro, 2007;23:(1)105-114.

6. Mcllelan, KCP, Barbalho SM, Cattalini M. Diabetes mellitus tipo 2, síndrome metabólica e modificações no estilo de vida. Rev. Nutr. 2007;20:(5)515-525.

7. Lottenberg SM, Glezer A, Turatti LA. Síndrome metabólica: identificando fatores de risco. J. Pediatr. 2007;83:(5)204-208.

8. Júnior $A B L$, Brito APC, Girardi CEB et al. Associação entre a aptidão cardiorrespiratória e acúmulo de componentes da síndrome metabólica em militares do sexo masculino do exército brasileiro. Revista de Educação Física 2007;138:2330.

9. Zimet P, Magliano D, Matsuzawa Y, et al. The Metabolic Syndrome: A Global Public Healt Problem And A New Definition. Jornal of Artherosclerosis and Thrombosis, 2005; 12:(6)295-300.

10. Teixeira PJR, Roch FL. Associação entre síndrome metabólica e transtornos mentais. Revista de Psicologia Clínica. 2007: 34:(1)28-38.

11. Räikkönen K, Matthews KA, Kuller LH. The relationship between psychological 
risk attributes and the metabolic syndrome in healthy women: antecedent or consequence? Metabolism. 2002;51:(12)1573-7.

12. Coutinho W. Consenso Latino-Americano de Obesidade, Arq Brás Endocrinol. Metab 1999;43:21-67.

13. Anastasi A, Urbina S. Testagem psicológica. 7a Ed. Porto Alegre: Artes Médicas 2000.

14. Spilberger CD, Gorsuch RL, Lushene RE. Inventário de Ansiedade Traço Estado. Rio de Janeiro: Centro Editor de Psicologia Aplicada-CEPA 1979.

15. Rumin CR. Sofrimento na Vigilância Prisional: O Trabalho e a Atenção em Saúde Mental. Psicologia Ciência e Profissão 2006;26:570-581.

16. Lipp MEN. O modelo quadrifásico do stress. In Lipp MNE Mecanismos neurofisiológicos do stress; teorias e aplicações clínicas (pp17-22). São Paulo: Casa do Psicólogo 2003.

17. Myers D. Introdução a Psicologia Geral;.5a Ed. Rio de Janeiro: Editora LTC- Livros Técnicos e Científicos 1999.

18. Reichert FF, Lopes M, Loch MR et al. Atividade Física e outros aspectos relacionados à saúde de Agentes Penitenciários de Londrina - PR. Revista Brasileira de Atividade Física \& Saúde 2008; 4-11

19. Tartaglini AJ Safran DA. Topography of psychiatric disorders among correction officers. Journal of Occupational and environmental Medicine, 1997;39:569-573.

20. Golberg P, Simone D, Landre MF et al. Work Condition and mental health among prison staff France. Scandinavian Journal of Work and Environmental Health 1996; 22:45-54.

21. Flegner AT Dias JC. Pesquisa, metodologia e redação de trabalhos científicos. In Rocha LR Aspectos diversos da medicina do exercício. Rio de Janeiro:Revinter 2004:1-32.

22. Biaggio $A M B$, Natalicio L. Manual para o inventário de ansiedade Traço-Estado (IDATE). Rio de janeiro, Centro Editor de Psicologia Aplicada-CEPA, 1979.

23. Ferreira DKS, Augusto LGS, Silva JM. Work conditions and health perceptions of military police members. Cad Saúde Coletiva 2008;16(3)403-420.

24. Souza MSF, Leme RB, Franco RR et al. Síndrome Metabólica em adolescentes com sobrepeso e obesidade. Ver Paul Pediatr 2007;25:(3)214-220.

25. Tritschler K. Medida e avaliação em educação física e esportes de Barrow e Mcgee, $5^{\text {a }}$ ed. Barueri-SP: Manole 2003.

26. Oliveira MS, Laranjeira R, Araujo RB et al. Estudo dos Estágios Motivacionais em Sujeitos Adultos Dependentes do Álcool. Psicologia: Reflexão e Crítica 2003; 16:(2)265-270

27. Laranjeira R, Pinsky I. O alcoolismo. São Paulo: Contexto 1997.

28. Gonçalves DM, Stein AT, Kapczinski F. Avaliação de desempenho do Self-Reporting Questionnaire como instrumento de rastreamento psiquiátrico: um estudo comparativo com o Structured Clinical Interview for DSM-IV-TR. Cad Saúde Pública 2008;24:(2)380-390.

29. Costa M, Accioly H, Oliveira J. Estresse: diagnóstico dos policiais militares em uma cidade brasileira. Revista pan-americana de Salud Pública, Washington 2007; $21:(4)$ 217-222.

30. Dantas HL, Andrade AG. Comorbidade entre transtorno de estresse pós-traumático e abuso e dependência de álcool e drogas: uma revisão da literatura. Rev psiquiatr clín 2008;.35(1).

31. Portela A, Filho AB. Nível de estresse de policiais militares: comparativo entre sedentários e praticantes de atividade física. Revista Digital- Buenos Aires 2007; 11:106.

32. Feldman A, Almeida AR, Grabarz R, et al. Análise da incidência dos fatore de risco para insuficiência coronariana em pacientes com infarto agudo do miocárdio no Hospital Geral do Grajaú. 2007. Disponível em:<http://unisa.br/ ligadecardio/arquivos/fatoresderisco.2001pdf>

33. Silva EMS. A Prevalência de diabetes mellitus tipo 2 e de tolerância diminuíd à glicose em homens de 30 a 59 anos da Polícia Militar de Teresina, Piauí. Tese apresentada na Escola Nacional de Saúde Pública, Rio de Janeiro: s. n. 2008.47:403-420.

34. Ciolac EG, Guimarães GV. Exercicio Fisico e Síndrome Metabólica. Rev Bras Med Esporte 2004;10:(4)319-324.

35. Calamita Z, Silva Filho CR Capputti PF. Fatores de risco para doenças cardiovas culares no policial militar. Revista Bras Med Trab 2010; 8:(1)39-45.

36. Donadussi C, Oliveira AF, Fatel ECS et al. Ingestão de lipídios na dieta e indicadores antropométricos de adiposidade em policiais militares. Rev Nutr Campinas 2009;22: (6)847-855.

37. Gus I, Fischmann A, Medina C. Prevalência dos fatores de risco da doença arterial coronariana no estado do Rio Grande do Sul. Arq Bras Cardio 2002;78:(5)484-490.

38. Lottenberg SA, Glezer A, Turatti LA. Síndrome Metabólica: Identificando fatores de risco. J.Peaditr.(Rio de Janeiro) 2007; 83:(5)204-208. 